Patton, A. R. \& Palmer, L. S. (1936). F. Nutrit. 11, 129.

Reindel, W. \& Schuler, W. (1937). Hoppe-Seyl. Z. 247, 172.

Riddle, O. \& Reinhart, W. H. (1926). Amer. F. Physiol. 76, 660.

Schuler, W. \& Reindel, W. (1935). Hoppe-Seyl. Z. 234, 63.

Sonne, J. C., Buchanan, J. M. \& Delluva, A. M. (1948a). Y. biol. Chem. 173, 69.

Sonne, J. C., Buchanan, J. M. \& Delluva, A. M. (1948b). F. biol. Chem. 173, 8r.

Stokstad, E. L. R., Almquist, H. J., Mecchi, E., Manning, P. D. V. \& Rogers, R. E. (194r). F. biol. Chem. 137,373 .

Tarchanoff, J. R. (1884). Pflüg. Arch. ges. Physiol. 33, 303.

Tyler, C. (1940). Biochem. F. 34, 202.

\title{
Practical Aspects of Poultry Feeding
}

\section{By T. E. Whitrle, Poultry School for Scotland, West of Scotland Agricultural College, Auchincruive, Ayr}

Before the war poultry in Britain were fed on mixtures composed largely of imported cereal products. Highly concentrated foods like maize and wheat were used in large quantities and a high efficiency of utilization was obtained. Cost of feeding was relatively very low, owing to the abundance and cheapness of imported cereals. For instance, in 1939, immediately before the war, it was possible to buy large quantities of Canadian wheat at $£_{5} /$ ton delivered on the farm. The price to-day is about $£_{25} /$ ton for non-millable wheat.

During the last to years both cereal and protein feeds have been very scarce, and the feeding of poultry, in common with that of pigs, has been dominated entirely by the effects of rationing. As both poultry and pigs compete strongly with human beings for cereal foods, severe rationing had to be applied, although in point of fact poultry are the most efficient of all farm animals in converting digestible protein (into eggs and meat), whereas pigs are the most efficient converters of energy or carbohydrate.

\section{Effects of rationing}

The system of rationing of poultry is based on the number of birds on the holding before the war, i.e. the 'basic' figure, and at the worst period in 1942 established commercial poultry keepers were rationed officially to one-eighth of the basic number, with an acreage deduction of four birds for every 3 acres as an additional restriction. Even to-day official rations to commercial producers are restricted to one-fifth of the pre-war basic figure, although in Britain the number of birds kept is almost as great as before the war, and in Scotland last year's returns exceeded nine million birds, the highest ever recorded. The rationing of pigs is on similar lines, although the numbers kept are little more than half those of pre-war. The main effects of rationing may be summarized as follows.

\section{Unrationed supplements}

Unrationed supplements are extensively used in an effort to feed more birds, often a sheer necessity in order to make a living. These foods are of two main types:

(a) Bulky watery foods, e.g. potatoes, carrots, house-scraps, and processed (steamed and evaporated) house-scraps from heavily populated areas, i.e. industrial 'pudding'. 
Potatoes are the most common product used, for they can often be purchased in large quantities for stock feed at $£ 3-4 /$ ton. They would be used to an even greater extent were it not for the need for cooking, which imposes a practical difficulty.

'These watery vegetable foods are normally used in amounts of up to half the total ration, although experiments have shown that up to 1o oz. of cooked potatoes may be used per bird daily, together with $2 \mathrm{oz}$. of a meal mixture. All these watery foods are lacking in protein, as even house-scraps now contain very little meat.

(b) Fibrous husky foods, e.g. oat and barley husks, dried grass and similar products. Although these are extensively used, especially in meal mixtures, they are of very limited value as, owing to the inability of the fowl to digest fibre, they merely act as fillers and serve to make the coupons go further without increasing the nourishment of the birds. Indeed, the inclusion of excessive fibre in a poultry ration is known to reduce the digestibility of other carbohydrates. The commonest product of this type is oatfeed, which consists of ground oat husks, produced in Scotland as a by-product from the manufacture of oatmeal. Oatfeed may be used to a limited extent as a filler, especially in rations to growing birds on good grass range, when potatoes are included in the diet. Often these unrationed fibrous supplements are used to an appreciable extent, sometimes from sheer necessity, but they have no real feeding value and merely increase the bulk of the ration.

\section{Home-grown foods}

There has been an increasing emphasis on home-grown foods, especially since the war. During the war, when the cereal shortage was acute, the feeding of millable wheat and barley to poultry was entirely prohibited, and even oats were restricted to the grower. To encourage poultry keeping on the general farm where the food is grown, these controls are gradually being relaxed, and it is now permissible to feed unlimited barley and up to $20 \%$ of home-grown wheat.

The future trend is likely to be still more in favour of the general farmer who is able to grow his own grain, owing to the continued shortage and rationing of imported feeding-stuffs and the call for increased tillage. Most of the subsidy on imported cereals has now been removed, resulting in an average increase in price of about $£ 7 /$ ton. This will mean a still greater emphasis on home-grown food, and the arable farmer will find it profitable to market his grain in the form of eggs.

\section{Feeding mixtures}

Feeding mixtures used by proprietary firms, who are the main source of supply, and 'straight' foods available to farmers who wish to mix their own rations, are carefully controlled by the Ministry of Food, under what is known as the 'protein and cereal split'. This stipulates the proportions of the various foods which may be purchased against ration coupons or buying permits; for cereals the proportions vary each month, according to supplies available.

Under these circumstances, it frequently happens that mixtures have to be compounded according to what is obtainable rather than what is desirable, and rations often 
have to be used which do not conform strictly to accepted feeding standards. Some mixtures may even be injurious, as was shown, for instance, by the outbreaks of 'six-day chick disease' during the war, which were eventually found to be caused by lack of available energy in the food.

The shortage of animal protein also leads to the use of oilseed proteins, which are not always suitable owing to high oil content or other injurious ingredients.

\section{Distribution of poultry population}

A fourth effect of wartime conditions which must be mentioned has been the very marked swing in poultry population, both in England and Scotland, from the industrial areas of the west to the grain-growing areas of the north and east. In Scotland there has been a tremendous increase in the north-east, especially in such counties as Aberdeen, Sutherland and Banff, where an increase of over $40 \%$ is reported in the period 1939-46. The two main reasons for this are:

(a) Home-grown grain is available for feeding. General farm flocks where grain is available have shown the greatest increase, in contrast to specialist undertakings depending on rationed supplies.

(b) These areas, being remote from large consuming centres, received a poor average price before the war, especially in the spring flush season, whereas they now enjoy an assured market and guaranteed prices under the Ministry of Food packing station system. Orkney, for instance, is reported to have the largest single packing station in Britain.

\section{The composition of rations}

Owing to the many difficulties of supply, poultry rations are usually calculated by farmers and food merchants by rule-of-thumb methods, for it is often very difficult to compile scientifically correct diets, or to maintain the same mixture for any length of time.

When supplies permit, poultry are normally fed on a meal mixture which may be given as wet mash, dry mash or in the form of pellets, together with an equal quantity of grain usually given as an evening meal. The grain may consist of wheat, barley or oats, either separate or as a mixture, and when insufficient grain is available all-mash feeding becomes necessary.

Most meal mixtures consist of $85-90 \%$ of ground cereals or cereal by-products, supplemented by the addition of $10-15 \%$ of protein-rich food. Wheat, barley, oats and maize, together with their by-products, are used in proportions determined largely by availability. Maize, being imported, is usually in shortest supply, and oats are generally most abundant. In mixing home-grown rations the usual difficulty is to avoid using too great a proportion of oats. Although rolled oats are sometimes used as the sole food for the first few days of the chick's life, in ordinary rations $35-40 \%$ oats is usually considered the safe maximum, owing to their fibrous nature; other cereals may be used in almost any proportion.

Before the war wheat offals, chiefly middlings and bran, were the main ingredients of poultry rations in this country, although in America much more maize was used. With 
the increase in the extraction rate of wheat to $85 \%$, the amount of offals available has been reduced to about half. Instead of the pre-war group of products ranging from bran to fine middlings we now have one product, straight-run bran, which comprises the whole of the $15 \%$ of the wheat not included in the flour. Bran is often rather scarce in winter, but is usually available in summer, when the demands of dairy cattle are reduced.

\section{Protein supplies}

Protein supplies are the greatest problem to the farmer who grows his own rations, for undoubtedly the best all-round protein supplement for poultry is white-fish meal, which can only be bought against scarce protein coupons.

There are differences of opinion between American and British workers regarding protein requirements, and the American figures are generally higher. These differences in feeding standards may be due, in part at least, to the high protein value of young grass in this country, where free range is common, in contrast to the position in America where most laying and even breeding flocks are housed intensively and receive very limited quantities of green food, probably none in winter.

There is, however, a tendency amongst practical feeders to use high-protein rations, owing to the stimulating effect of protein, especially from animal sources, on growth and egg production. This is most marked with mixtures for birds in intensive or laying battery houses, where the maximum egg output is desired. Too much protein is injurious and leads to digestive trouble and kidney breakdown.

Farmers buying 'straight' foods prefer to purchase as much protein as possible in the form of fish meal, the most valuable of the animal proteins. Feeding-stuff ration coupons are issued in the ratio of one protein to nine cereal, which will theoretically allow $10 \%$ of protein-rich food, normally ample for growth or egg production. In practice, however, the cereal part of the ration is often 'stretched' by the addition of unrationed supplements, which have the effect of reducing the proportion of protein. Fish meal is sometimes difficult to obtain, and there is a constant search for substitutes.

Milk proteins, particularly liquid or dried skim milk, are highly valued for poultry feeding, but their scarcity and high price usually limit them to the feeding of young chicks. Dried skim milk can sometimes be obtained in small quantities against special chick coupons, and it is considered worth feeding to chicks even at $£_{3} / \mathrm{cwt}$. Calfstarter meal also contains a high proportion of dried skim milk, and farmers can sometimes spare a little of this for addition to chick rations. When available, dried skim milk is given at the $5 \%$ level; liquid skim milk may be given to chicks to drink, or used to mix wet mash.

Dried yeast is unrationed, and is an excellent source of protein for chicks or breeding stock, especially as it is rich in the B-complex group of vitamins. Being unrationed it is, however, very scarce and is apt to be rather high in price, but it should be given to breeding stock and chicks at the 3-5\% level whenever it is obtainable. It should not be included at a higher level than $10 \%$ or it will depress growth, and it should not, therefore, be used as the sole protein food.

The remaining protein supplement has to be made up from vegetable sources, but 
the choice here is rather restricted, as most of the oilseed by-products are unsuitable for poultry owing to their inadequate protein quality as supplements to cereal proteins. Extracted soya-bean meal is an exception, it is an excellent protein feed for poultry and may be used to replace at least part of the animal protein if supplemented with minerals, particularly steamed bone-flour and salt. Soya-bean meal is produced in America, and is extremely scarce at present. Various other oilseed products, such as palm-kernel-cake meal, decorticated ground-nut meal, sunflower-seed meal and coconut meal, may be used for poultry feeding to a limited extent, say up to $5 \%$.

Farmers use bean meal and pea meal as home-grown proteins for poultry; both are quite useful and may form up to 10\% of the total ration. Ground linseed may also be used to a limited extent, up to $3 \%$, but as the minimum grower's price for millable linseed is $£ 55 /$ ton, few farmers are likely to use it for poultry feeding. None of these vegetable products are suitable as the sole source of protein.

Dried-grass meal is an essential ingredient in all poultry rations when the birds do not have access to fresh grass, i.e. for young chicks, intensive layers and birds in laying cages. The usual level is $5 \%$ for chicks and up to Io $\%$ for adult birds, the limiting factors being high fibre content and high price. For poultry feeding it is essential to use dried grass of the highest quality, high in protein and carotene and low in fibre, material made from the youngest and shortest cut of grass being the best. Besides being a good source of protein, dried grass is fed to supply carotene, the precursor of vitamin $A$, as well as minerals.

\section{Minerals and vitamins}

No description of the ingredients used in poultry rations would be complete without mention of mineral and vitamin supplements. The chief minerals required in quantity are calcium, phosphorus and salt. Calcium, required in relatively large quantities for egg-shell formation, is normally supplied to laying birds in the form of a box or hopper of oyster shell or limestone grit. This is a good method provided the hopper is kept full, as each bird can meet its own individual requirement. Alternatively, and as a safeguard, it is common for proprietary firms to include $2 \%$ limestone flour in poultry mixtures. If the level of fish meal in the ration is $5 \%$ or more it will supply sufficient salt, but if other animal proteins are used $0.5 \%$ of salt should be included, and if the protein is entirely of vegetable origin $0.5-1 \%$ sterilized steamed bone flour should also be added. The inclusion of manganese sulphate at the rate of $4 \mathrm{oz}$./ton is recommended for chicks and breeding stock; it is usually added to salt at the rate of $2 \frac{1}{2} \mathrm{lb} . / \mathrm{cwt}$., i.e. $4 \mathrm{oz}$. in $10 \mathrm{lb}$., the salt being included in the ration at the normal rate of $0.5 \%$.

Vitamin requirements are usually taken care of by the inclusion of $5 \%$ dried grass for vitamin A and riboflavin, bran or dried yeast for vitamin B complex, and cod-liver oil for vitamins $A$ and $D$. Cod-liver oil is normally mixed in the mash at the rate of $x \%$, but the rate should of course vary according to the potency of the oil, especially in regard to vitamin $\mathrm{D}$. Cod-liver oil should always be included in rations for breeders and young chicks, as well as for all birds kept under intensive conditions.

Table I gives a number of specimen mash mixtures for different classes of poultry. These have not been compounded to exact scientific requirements, for, as was 


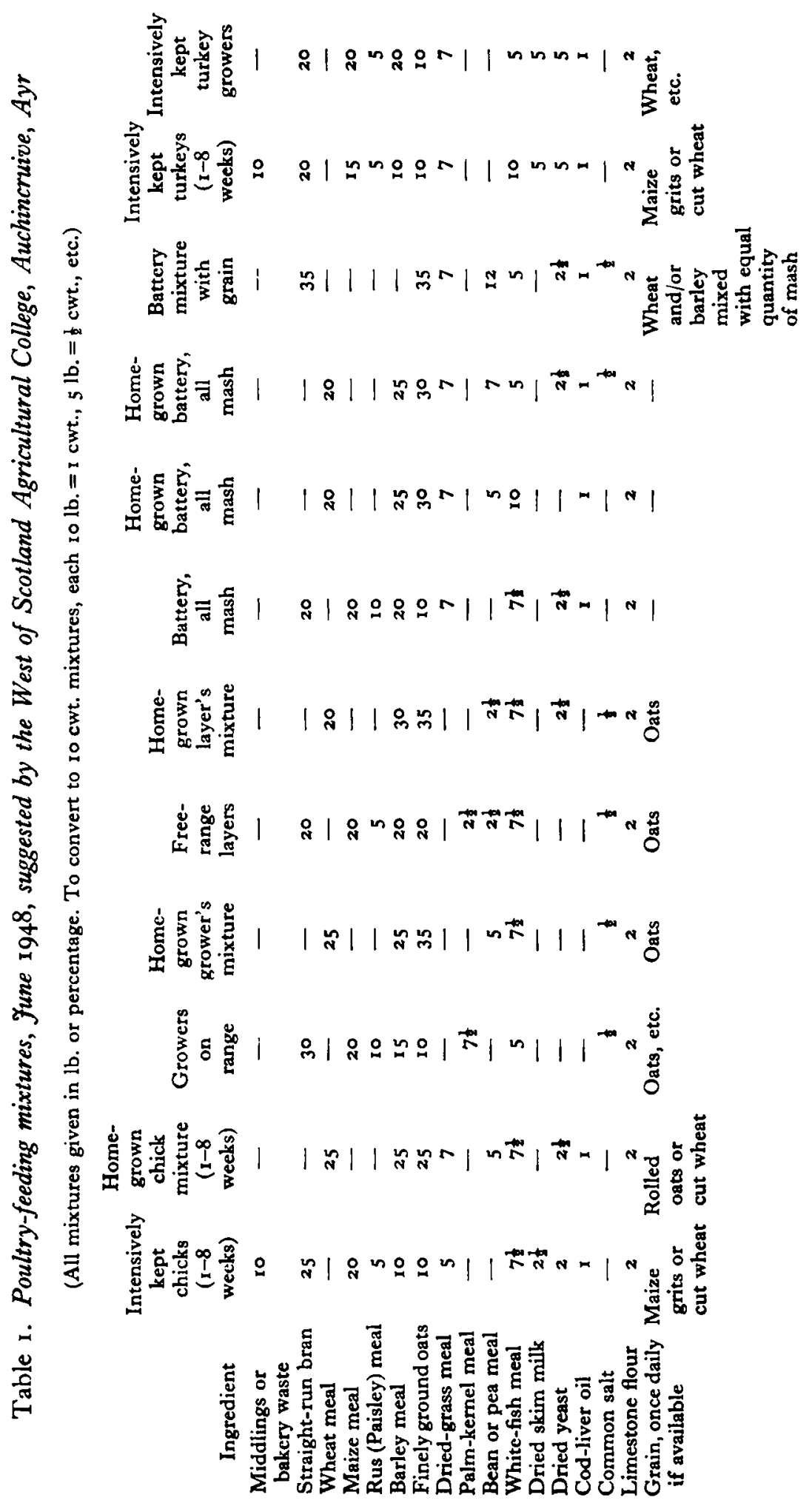


explained earlier, this is very difficult under present supply conditions. They are all reasonably well balanced, however, and have given good results in practice. The mixtures are all intended for wet or dry feeding, but the same formulas could be used to produce pellets. Several home-grown mixtures are included for the benefit of general farmers, some of which almost entirely eliminate the need for purchased foods, fish meal being the only rationed ingredient not home-grown.

A supply of hard insoluble grit is essential for all birds to facilitate the grinding of the food in the gizzard. Birds running out on gravelly soil can normally pick up sufficient, but all others should receive a regular supply of hard flint grit. A convenient method is to mix a little flint grit with the limestone grit in a hopper, or to provide a box alongside. It is important to prevent the birds consuming an excessive quantity of calcium grit in their desire to obtain insoluble grit.

\section{Practical feeding methods}

Practical methods of feeding are dictated largely by the type of housing and the amount of labour available. There is much difference of opinion among practical men as to the best method, but it is probable that circumstances play a big part. The various methods may be listed as follows: $(a)$ wet mash and grain; $(b)$ dry mash and grain; (c) wet mash, dry mash and grain; (d) all (dry) mash; (e) pellets, with or without grain.

(a) Wet mashes are made by mixing the meal with water to a crumbly consistency. Hot water may be used in winter, and separated milk is sometimes available for chick mashes. There can be no doubt that wet mash is most appetizing to the birds, and this system generally gives the best results, especially in cold wintry weather. Labour requirements are high, particularly if the birds are widely scattered, but mechanization is possible, and the system is fully justified by the improved results. There is very little waste when wet mash is fed skilfully, an important point when feeding-stuffs are so scarce. The usual method is to give the wet mash as an early morning feed, grain, if available, being given before the birds go to roost.

(b) In contrast, dry-mash feeding is the more labour saving, since the dry meal may be emptied directly from the sack into hoppers in the houses, from which the birds help themselves. The hoppers need only be filled once a week, and if grain is stored in a handy bin much of the labour of feeding is reduced. This system is naturally popular when poultry are kept in scattered flocks on the general farm, but there is a greater or lesser amount of waste, according to the design of the hoppers, in addition to losses from vermin.

(c) The third method, wet mash, dry mash and grain, is obviously a compromise aimed at securing the advantages of both the above methods. The birds are given a light feed of wet mash in the early morning, and a feed of grain in the early evening, dry mash being available during the day. This is a very good method in the long days of summer, particularly for growing stock, as the supply of dry mash ensures that they will not go hungry. It also tends to keep the birds to their own houses.

$(d),(e)$ All dry mash or all pellets are the two methods adopted for birds in laying batteries or for young chicks. The saving of labour is the main consideration, but for 
chicks dry mash is by far the simplest method of feeding. Wet mash may be introduced later as the birds grow. Pellets are very popular for feeding in laying batteries, as they are well liked by the birds and waste is reduced to a minimum.

The amount of feed consumed by laying birds varies between 4 and $6 \mathrm{oz}$./bird daily, depending upon the composition of the ration, and especially its fibre content and bulkiness, and on the size of bird and rate of production. The tendency to-day is for a layer to consume about $6 \mathrm{oz}$. daily, owing to the lower energy value of rations, in contrast to about $4 \frac{1}{2} \mathrm{oz}$. daily with pre-war rations. A laying hen consumes rather more than I cwt. a year. Growing birds may be expected to put on $\mathrm{I} \mathrm{lb}$. live-weight increase for each $4 \mathrm{lb}$. food up to the age of about 16 weeks, the ratio widening to $\mathrm{I}: 5$ or even I : 6 as the birds approach maturity at 6 months old.

\section{The future trend}

What of the future trend in poultry feeding? There are definite signs that the cereal shortage in the world as a whole is passing; in fact, the shortage here is now one of dollars rather than of feeding-stuffs. An increase in tillage has been called for from the farmers, and we may hope that the easing of the dollar crisis will result in an everincreasing flow of feeding-stuffs, so that the burden of rationing may be removed.

The shortage of protein in the world as a whole may persist for some time, and our problem is therefore to intensify the development of home sources.

\section{SUMMARY AND CONCLUSIONS}

I. Poultry are fed on highly concentrated rations consisting of cereals and their byproducts, supplemented with 10-1 $5 \%$ of protein-rich foods. They cannot digest fibre, but the diet should contain from 6 to $10 \%$ crude fibre in order to keep the mixture open and to promote peristaltic action.

2. In time of war fowls, the most efficient of all farm animals in the conversion of food protein (into eggs and meat), compete seriously with human beings for cereal supplies. As dairy cows can deal with coarse fodders, priority has to be given to them.

3. The effect of rationing over the last 9 years has forced producers to make the maximum use of unrationed supplements and home-grown grains. Poultry rations have become less concentrated and more fibrous, food consumption per bird has increased, but there has been an improvement in health, and stocks have been maintained at a remarkably high level.

4. There has been a marked increase in poultry population in the arable counties of the north and east, and poultry are now the third highest source of farm income in Scotland, being second only to milk products and cattle, and exceeding all grain crops combined. In 1946-7 eggs and poultry were estimated to contribute $9.6 \%$ of the total farm income in Scotland. As there was a $17 \%$ increase in flocks in 1948 , this figure will now be higher.

5. Owing to the changing supply position, it is not always possible to apply exact scientific formulas in the construction of poultry rations. The cereal portion is made up 
from wheat, barley, oats and maize, the proportions being determined largely by availability. Maize, being imported, is in shortest supply, and oats are the most abundant.

6. Animal proteins are the most valuable for poultry feeding, and feeders prefer to convert their protein coupons into fish meal. The use of unrationed cereal supplements tends to widen the ration and reduce the proportion of animal protein, so that vegetable proteins, notably extracted soya-bean, earthnut, sunflower and palm-kernel meals, bean meal and pea meal have to be used as supplements. The three last foods contain less than $25 \%$ protein, and can be bought against cereal coupons. Milk proteins are highly valued for chick feeding.

7. Fish meal, besides being the best all-round source of protein, is rich in minerals and, if $5 \%$ or more is used, the only mineral supplement required is calcium, which can be provided as calcium grit ad lib., or by the addition of $2 \%$ limestone flour to the ration. The former method is preferred for laying birds, the latter for chicks and growing stock. Intensively kept birds also need occasional supplies of flint grit as a grinding medium. Rations not containing fish meal also require the addition of $0.5 \%$ of common salt.

8. Dried yeast is a valuable protein food and is an excellent source of the vitamin $B$ complex. High-quality dried grass meal is given at a $5-10 \%$ level as a source of provitamin $A$ to intensively kept birds, and the addition of $\mathrm{I} \%$ of cod-liver oil is the standard method of providing vitamin $\mathrm{D}$.

9. Practical methods of feeding vary according to circumstances. Wet mash and grain gives the best results; dry-mash feeding saves labour but is more wasteful. Intensively kept birds, especially when in laying batteries, are normally given dry mash or pellets ad lib. Pellets are becoming very popular, as they are very convenient and are well liked by the birds.

10. Only $60 \%$ of the present egg ration of about eighty eggs a year per person is provided from home production. There is a vast potential scope for expansion of the poultry industry, especially when it is realized that in America the annual consumption of eggs is about 375 per person. Scarcity of feeding-stuffs is the major limiting factor, but the efficiency of production will have to be increased to meet the harder economic conditions of the future. 